\title{
Perancangan Storyboard Konten Animasi 3 Dimensi Untuk Edukasi Anak Usia Sekolah Dasar Tentang Mitigasi Penyebaran COVID-19
}

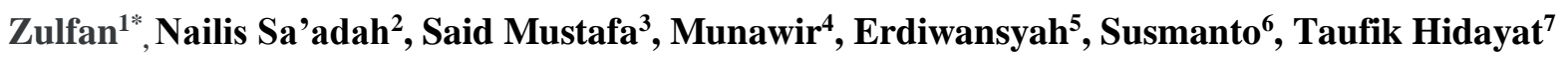 \\ 1,2,3,4,5,6,7Program Studi Teknik Komputer Universitas Serambi Mekkah \\ *Koresponden email : zulfanzainal@serambimekkah.ac.id
}

Diterima: 14 November 2021

Disetujui: 16 Desember 2021

\begin{abstract}
The spread of the COVID-19 virus has been widespread all over the world since its discovery in 2019. However, the spread of this virus can be prevented by means of health protocols conforming to World Health Organization standards. The Indonesian government continues to educate the public, especially school-aged children, to understand how to implement the health protocol. On the basis of the foregoing, it is necessary to carry out research on the creation of an interactive media based on multimedia content that can be used to educate on COVID-19 prevention, specifically for elementary school children. The research begins with problem analysis, storyboard writing, creating 3D animation characters, and merging all content into a complete 3D animation video. The results of this study are 3D animated multimedia content which presents 3D animated scenes on the application of health protocols such as hand washing with soap, wear masks and keep distance.
\end{abstract}

Keywords: Covid-19, mitigation, health protocol, animation, multimedia

\begin{abstract}
Abstrak
Penyebaran virus Covid-19 sudah sangat meluas di seluruh dunia sejak ditemukan tahun 2019. Penyebaran virus ini dapat dicegah melalui protokol kesehatan sesuai standar World Health Organization. Pemerintah Indonesia terus mengedukasi masyarakat khususnya anak usia sekolah dasar untuk memahami cara penerapan protokol kesehatan tersebut. Berdasarkan latar belakang maka penelitian ini bertujuan untuk membuat sebuah media interaktif berbasis konten multimedia yang digunakan untuk mengedukasi pencegahan Covid-19 khususnya untuk anak usia sekolah dasar. Penelitian diawali dengan analisa masalah, penulisan storyboard, pembuatan karakter animasi 3D dan penggabungan semua konten agar menjadi video animasi 3D yang utuh. Hasil penelitian ini berupa konten multimedia animasi 3D yang menampilkan scenescene animasi 3D tentang penerapan protokol kesehatan seperti mencuci tangan dengan sabun, memakai masker dan menjaga jarak.
\end{abstract}

Kata Kunci : Covid-19, mitigasi, protokol kesehatan, animasi, multimedia

\section{Pendahuluan}

Penyebaran Covid-19 terus meningkat sejak ditemukan pertama sekali pada tahun 2019. Hal ini terjadi karena pemahaman masyarakat dalam melakukan langkah-langkah pencegahan masih sangat minim [1]. Oleh karena itu, untuk meningkatkan pemahaman tersebut Pemerintah Republik Indonesia sudah melakukan berbagai upaya untuk mengedukasi masyarakat tentang penerapan protokol kesehatan untuk mencegah penyebaran virus tersebut. Promosi tentang edukasi pencegahan Covid-19 dilakukan pemerintah baik secara langsung atau melalui media cetak dan elektronik. Edukasi ini dilakukan untuk semua lapisan masyarakat baik untuk usia dini dan sekolah dasar, masyarakat usia produktif ataupun lansia [2]. Akan tetapi, edukasi yang diberikan kepada anak usia sekolah dasar belum dapat meningkatkan pemahaman yang baik pada kelompok usia tersebut.

Hal ini disebabkan karena konten-konten yang digunakan sebagai media edukasi belum cukup menarik dan sulit dipahami. Berdasarkan hal tersebut maka dalam penelitian ini diajukan sebuah metode peningkatan pemahaman edukasi tentang mitigasi penyebaran covid-19 dengan menggunakan konten aplikasi berbasis multimedia animasi. Dalam penelitian ini akan diciptakan sebuah konten yang menarik dan mudah dipahami oleh anak usia sekolah dasar tentang pencegahan Covid-19 sehingga mereka mampu menerapkan langkah-langkah mitigasi tersebut dalam kehidupan sehari-hari.

Berdasarkan latar belakang maka permasalahan yang muncul dalam penelitian ini adalah bagaimana merancang storyboard konten media edukasi mitigasi penyebaran Covid-19 untuk anak usia sekolah dasar yang mudah dipahami sehingga mereka mampu untuk mengaplikasikannya dalam kehidupan sehari-hari. Tujuan dari penelitian ini adalah perancangan storyboard media edukasi untuk mitigasi penyebaran Covid- 
19 bagi anak usia sekolah dasar berbasis konten multimedia animasi. Diharapkan storyboard yang dirancang menjadi acuan pembuatan konten animasi yang mampu meningkatkan pemahaman anak usia sekolah dasar dalam mencegah penyebaran Covid-19. Tujuan dari penelitian ini adalah untuk membuat konten animasi 3D yang dapat digunakan untuk memberikan edukasi tentang protokol kesehatan untuk anak usia sekolah dasar.

\section{Metode Penelitian}

Dalam melakukan penelitian ini, terdapat langkah-langkah penelitian yang sudah ditentukan. Tahap pertama adalah melakukan analisa masalah dengan mengumpulkan data baik melalui data lapangan ataupun studi literatur. Data-data tersebut kemudian diolah agar dapat ditentukan bagaimana konten multimedia yang harus diproduksi sehingga sesuai dengan tema penelitian. Tahap berikutnya adalah penyusunan alur cerita/ storyboard untuk menentukan arah informasi sehingga tidak keluar dari jalur [3][4]. Setelah storyboard selesai, maka dilakukan pembuatan konten animasi [5]. Pembuatan konten animasi dimulai dengan mendesain objek-objek tokoh peran, melakukan penggabungan objek tersebut, mengisi suara dan melakukan rendering agar dihasilkan konten yang utuh. Gambar 1 menunjukkan langkah-langkah yang dilakukan dalam metode penelitian.

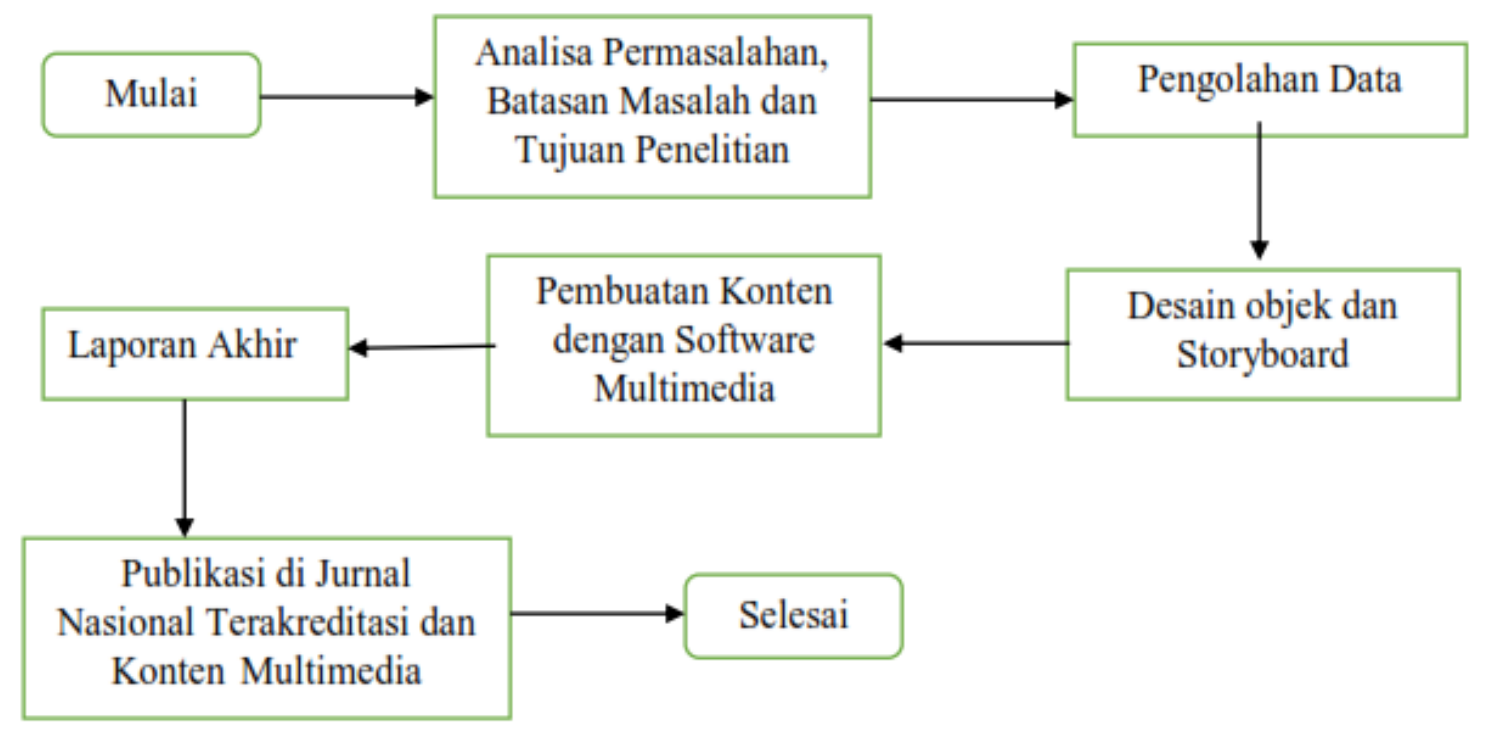

Gambar 1. Alur Penelitian

Sumber: Data peneliti (2021)

Analisa permasalahan dilakukan dengan mencari referensi-referensi terkait dengan virus Covid-19 dan melakukan pemantauan langsung di titik-titik perkumpulan anak-anak usia sekolah dasar. Hasil pemantauan dan pengumpulan referensi dijadikan sebuah data untuk penelitian yang kemudian data tersebut diolah menjadi data yang akan digunakan untuk melakukan langkah penelitian selanjutnya. Adapun data-data yang dikumpulkan adalah tentang tingkat pemahaman anak terhadap virus Covid dan tingkat ketertarikan informasi anak tentang virus Covid-19.

Berikutnya, dilakukan penyusunan storyboard dan desain objek tokoh animasi yang sesuai dengan kebutuhan anak usia sekolah dasar [6][7]. Hal ini bertujuan agar informasi yang akan disampaikan tentang pencegahan Covid-19 dapat dipahami dengan mudah oleh anak-anak tersebut. Storyboard berisi alur cerita tentang pencegahan Covid-19 dan juga tentang langkah-langkah yang harus dilakukan agar terhindar dari paparan virus tersebut [8]. Pada akhir alur cerita disampaikan pesan-pesan kepada anak-anak usia sekolah dasar agar menjaga kebersihan dengan selalu mencuci tangan, memakai masker dan menjaga jarak supaya terhindar dari virus Covid-19.

Setelah storyboard selesai dikerjakan, maka langkah selanjutnya adalah pembuatan objek-objek animasi yang sesuai[9]. Objek-objek animasi tersebut didesain menggunakan aplikasi animasi 3D sehingga tampilan objek mendekati objek sebenarnya. Kemudian objek-objek yang sudah dibuat akan digabungkan sehingga menjadi sebuah konten animasi 3D yang utuh sehingga dapat dinikmati oleh anak-anak usia sekolah dasar. Dalam penggabungan objek-objek animasi tersebut juga dilakukan pengisian suara/dubbing. Suara yang akan dimasukkan direkam terlebih dahulu dengan aplikasi perekam suara dan selanjutnya 
dilakukan pengeditan dengan aplikasi sound editing sehingga suara dapat terdengar jelas dan jernih. Penggabungan konten menggunakan beberapa aplikasi animasi seperti Blender, Adobe Primer dan Adobe Photoshop [10][11].

\section{Hasil dan Pembahasan}

Hasil perancangan storyboard dan konten animasi 3D tentang edukasi pencegahan virus Covid-19 untuk anak usia sekolah dasar adalah sebagai berikut:

\subsection{Storyboard}

Tabel 1 menunjukkan hasil perancangan storyboard animasi tentang pencegahan Virus Covid-19 untuk anak usia sekolah dasar.

Tabel. 1 Storyboard Perancangan Animasi

\begin{tabular}{|c|c|c|c|c|}
\hline Scene & Board & & Story & Durasi \\
\hline Scene 1 & 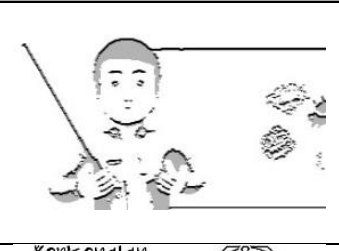 & Cerita & $\begin{array}{l}\text { Pada scene pertama ini menceritakan } \\
\text { asal mula dan bahaya covid-19. Jadi } \\
\text { pada scene ini dokter berharap semua } \\
\text { masyarakat bisa menjaga cepatnya } \\
\text { penyebaran virus corona dengan cara } \\
\text { melaksanakan prokes. }\end{array}$ & $\begin{array}{l}120 \\
\text { Detik }\end{array}$ \\
\hline Scene 2 & 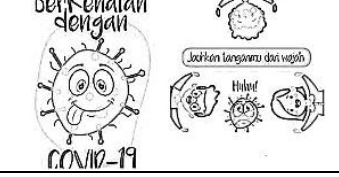 & $\begin{array}{l}\text { Dialog/ } \\
\text { Musik }\end{array}$ & $\begin{array}{l}\text { Pada scene kedua ini menampilkan } \\
\text { animasi dan tetap menceritakan alur } \\
\text { penyebaran covid-19. }\end{array}$ & 75 detik \\
\hline Scene 3 & & $\begin{array}{l}\text { Dialog/ } \\
\text { Musik }\end{array}$ & $\begin{array}{l}\text { Pada scene ketiga ini menceritakan } \\
\text { bagaimana cara mengecek suhu tubuh, } \\
\text { jika hasil cek suhu tidak normal, maka } \\
\text { langsung hubungi dokter dan isolasi } \\
\text { mandiri. }\end{array}$ & 34 detik \\
\hline Scene 4 & 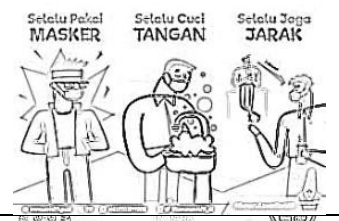 & $\begin{array}{l}\text { Dialog/ } \\
\text { Musik }\end{array}$ & $\begin{array}{l}\text { Pada scene keempat ini salah satu } \\
\text { menjaga tersebarnya virus covid-19 } \\
\text { yaitu dengan 3M yaitu jaga jarak, cuci } \\
\text { tangan dan pakai masker }\end{array}$ & 60 detik \\
\hline Scene 5 & 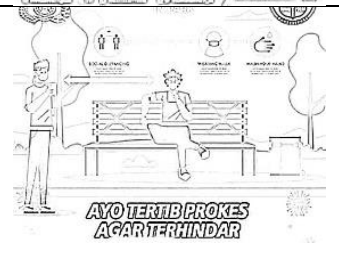 & $\begin{array}{l}\text { Dialog/ } \\
\text { Musik }\end{array}$ & $\begin{array}{l}\text { Pada scene kelima ini, perintah } \\
\text { pertama adalah jaga jarak, kemudian } \\
\text { dokter tetap menjelaskan bagaimana } \\
\text { konsep dari jaga jarak. }\end{array}$ & 80 detik \\
\hline Scene 6 & 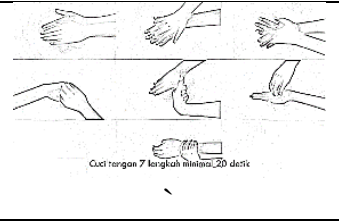 & $\begin{array}{l}\text { Dialog/ } \\
\text { Musik }\end{array}$ & $\begin{array}{l}\text { Pada scene keenam ini menampilkan } \\
\text { cara cuci tangan yang benar. }\end{array}$ & 60 detik \\
\hline
\end{tabular}




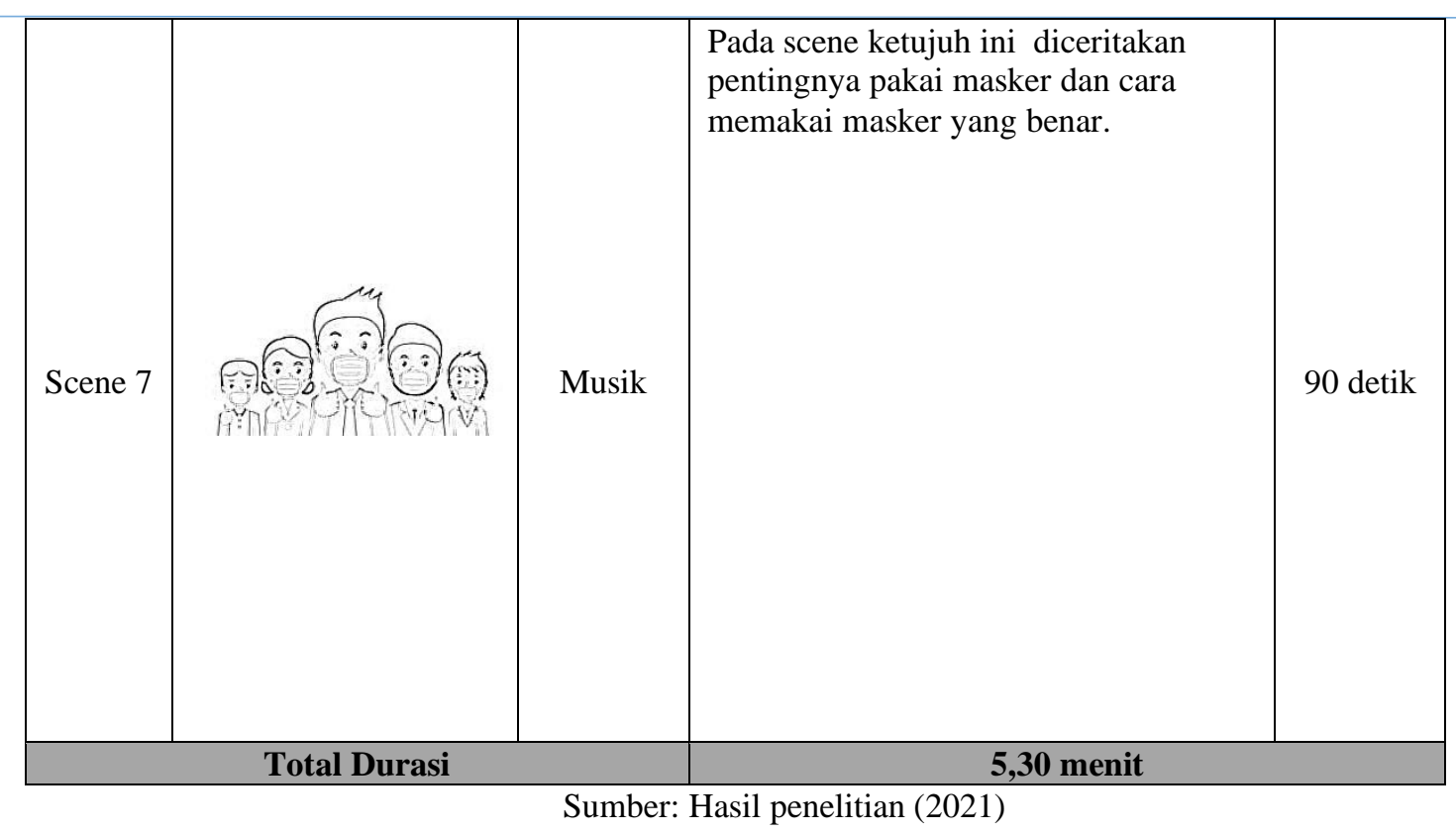

Storyboard yang dirancang terdiri 7 scene alur cerita dengan durasi waktu bervariatif antara $34-120$ detik per scene. Scene storyboard yang paling sedikit durasinya adalah pada scene 3 dengan durasi 34 detik. Pada scene ini menceritakan tentang cara melakukan pengecekan suhu. Dalam scene ini ditampilkan juga langkah-langkah yang harus dilakukan jika pada saat dilakukan pengecekan suhu menunjukkan nilai diatas batas normal[12][13]. Sedangkan scene yang paling panjang durasi waktunya adalah scence 1 dengan durasi waktu 120 detik. Pada scene ini menceritakan tentang virus Covid-19 dan awal mula ditemukan virus tersebut.

Alur cerita yang panjang inilah sehingga menyebabkan durasi waktu hingga 120 detik. Durasi keseluruhan scene dalam konten animasi 3D ini adalah 519 detik atau setara dengan 8.65 menit. Durasi ini dianggap sudah cukup memberikan pemahaman bagi anak usia sekolah dasar tentang langkah-langkah yang mesti dilakukan untuk mencegah penyebaran virus Covid-19[14][15].

\subsection{Konten Animasi 3D}

Konten animasi 3D tentang edukasi pencegahan penyebaran virus Covid-19 untuk anak usia sekolah dasar dapat dilihat pada gambar-gambar di bawah ini:

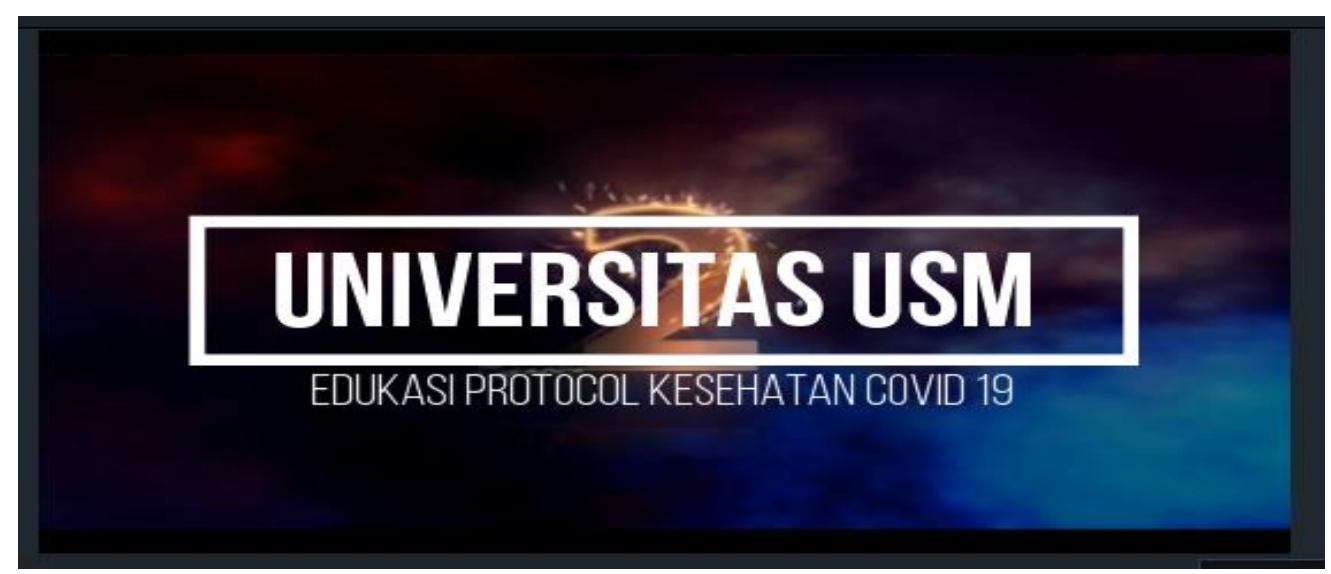

Gambar 2. Welcome Introduction

Sumber: Hasil penelitian (2021)

Pada Gambar 2 terlihat scene Fakultas Teknik Universitas Serambi Mekkah yang beralamat di Tgk. Imum Lueng Bata, Batoh, Lueng Bata, Kota Banda Aceh, Aceh 23122, Indonesia. Iklan masyarakat tentang penerapan protokol kesehatan yang di desain ke dalam objek 3 dimensi ini di lakukan berdasarkan pengamatan penulis di lapangan selama penelitian. Dari desain yang dilakukan ini, maka penulis menyimpulkan bahwa objek tentang protokol kesehatan tentang Covid-19 di masyarakat ini hampir dipastikan mirip dengan yang aslinya. 


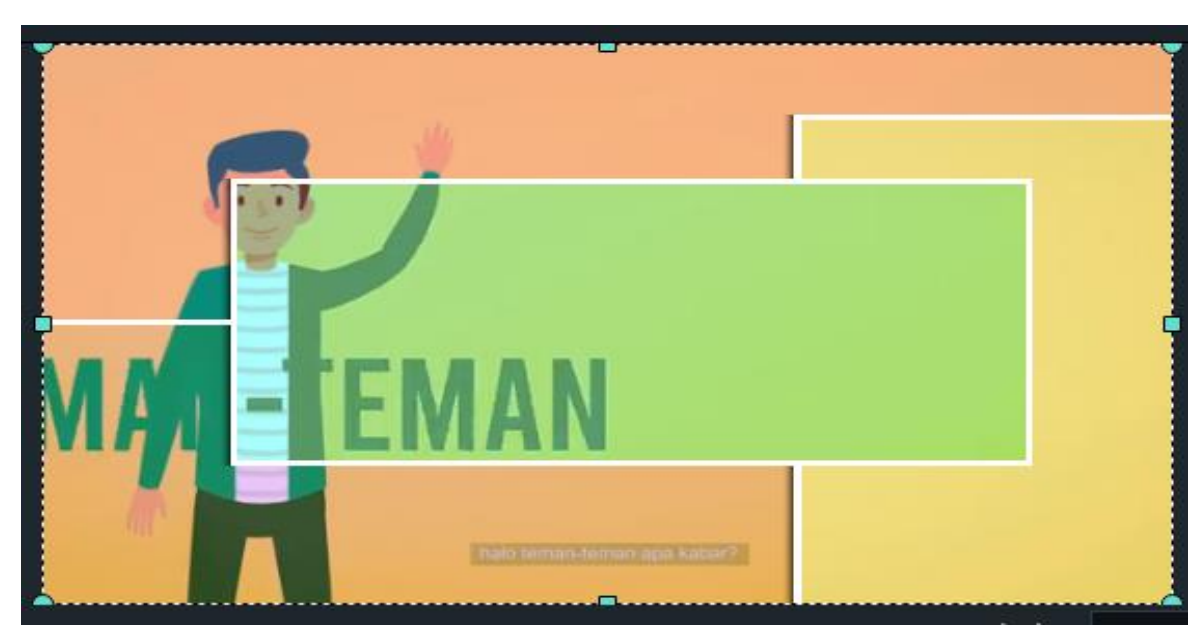

Gambar 3. Tampilan Karakter Utama Sumber: Hasil penelitian (2021)

Gambar 3 menunjukkan hasil desain karakter utama tokoh yang akan menjelaskan prosedur pencegahan Covid-19. Karakter yang didesain disesuaikan dengan kebutuhan pengguna yang akan melihat animasi 3D ini. Sesuai dengan peruntukan bagi anak usia sekolah dasar, maka pemilihan bentuk karakter, warna tulisan dan latar warna dilakukan dengan kombinasi warna yang berbeda. Hal ini dilakukan agar konten menarik ketika dilihat.

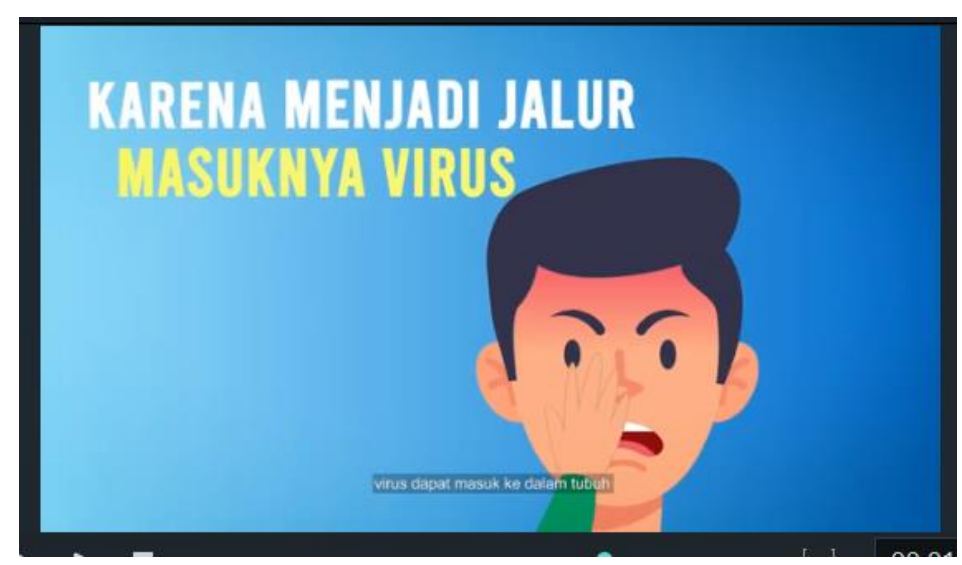

Gambar 4. Penjelasan tentang virus Covid-19 Sumber: Hasil penelitian (2021)

Gambar 4 menampilkan konten yang akan menceritakan tentang bagaimana proses penyebaran virus Covid-19 terjadi. Tampilan konten tersebut juga dibuat sedemikian rupa dengan desain karakter dan pewarnaan yang menarik sehingga anak-anak usia sekolah dasar lebih konsentrasi ketika melihat konten tersebut.
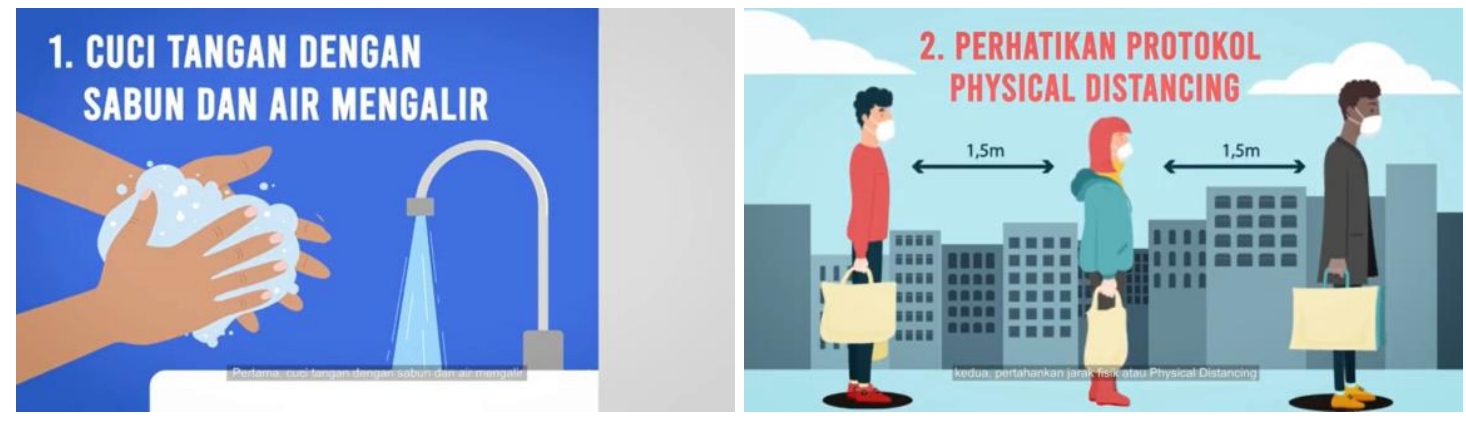

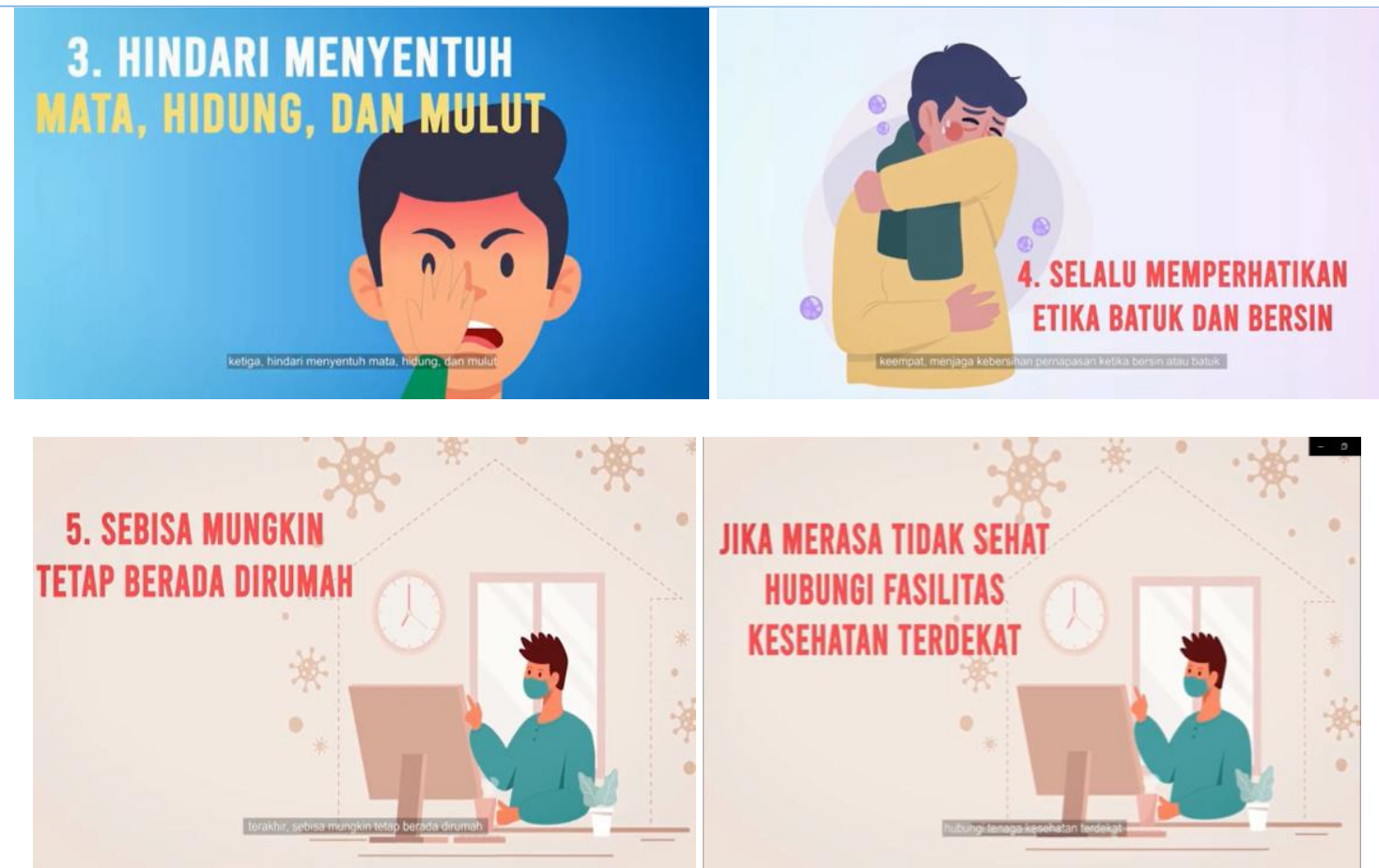

Gambar 5. Langkah-langkah pencegahan.

Sumber: Hasil penelitian (2021)

Gambar 5 menunjukkan konten yang akan menginformasikan tentang langkah-langkah yang harus dilakukan agar terhindar dari paparan virus Covid-19. Seperti pada scene-scene sebelumya, pada scene ini juga dilakukan pemilihan karakter dan warna yang menarik untuk ditonton oleh anak usia sekolah dasar.

\section{Kesimpulan}

Berdasarkan hasil penelitian, disimpulkan bahwa storyboard dan konten animasi 3D untuk pencegahan Covid-19 sudah berhasil dilakukan dan telah ditampilkan sejumlah scene tentang protokol kesehatan dengan durasi waktu 8,65 menit. Animasi ini sudah layak ditampilkan dalam berbagai kampanye pencegahan penyebaran virus Covid-19. Animasi ini relative mudah dirancang dan dibuat hingga jadi serta mudah ditampilkan dihadapan publik.

\section{Daftar Pustaka}

1. Z. Zulfan, D. Satria, and F. Akbar, "Perancangan Permainan Rescue-Heli Online Berbasis Macromedia Flash,” J. Nas. Komputasi Dan Teknol. Inf., vol. 1, no. 1, 2018.

2. Z. Zulfan and B. Baihaqi, "Pemanfaatan Konten Multimedia Animasi Dua Dimensi sebagai Media Pelestarian Alat Musik Etnik Aceh," J. Nas. Komputasi dan Teknol. Inf., vol. 1, no. 2, 2018.

3. B. Baihaqi, M. Maulinda, and M. Ulfa, "Perancangan Animasi 3D Gedung Fakultas Teknik Universitas Serambi Mekkah Sebagai Media Informasi,” J. Nas. Komputasi dan Teknol. Inf., vol. 2, no. 1, pp. 79 85, 2019.

4. R. Islamadina, Z. Zulfan, and A. A. Barat, "Media Interaktif Pelajaran Sains dengan Fokus pada Materi Fisika Energi Untuk Tingkatan SMP,” J. Nas. Komputasi dan Teknol. Inf., vol. 2, no. 2, pp. 193-201, 2019.

5. Zulfan and Samsuddin, "Analisa \& Perancangan Edukasi Keamanan Berlalu Lintas bagi Masyarakat Berbasis Konten Multimedia Animasi," Anal. Peranc. Edukasi Keamanan Berlalu Lintas bagi Masy. Berbas. Konten Multimed. Animasi, vol. 1, no. 1, pp. 22-30, 2016.

6. Adinda dan Adjie, Film Animasi 2d Berbasis 3d Menggunakan Teknik Cell Shading Berjudul The Postman Story", Stikom, Surabaya, 2011

7. Keputusan Menteri Kesehatan Nomor HK.01.07/MENKES/382/2020. Tentang Protokol Kesehatan Bagi Masyarakat di Tempat dan Fasilitas Umum Dalam Rangka Pencegahan dan Pengendalian Corona Virus Disease 2019 (COVID-19).

8. Munir, "Multimedia dan Konsep Aplikasi Dalam Pendidikan" Penerbit Alfabeta, Bandung 2013

9. Ahmadian, H., Satria, D., \& Kurniawan, S, "Progress of construction project information system based on SMS gateway", Jurnal Nasional Komputasi Dan Teknologi Informasi (JNKTI), 1(2), 2018 
10.Islamadina, R., Zulfan, Z., \& Barat, A. A., "Media Interaktif Pelajaran Sains dengan Fokus pada Materi Fisika Energi Untuk Tingkatan SMP”, Jurnal Nasional Komputasi Dan Teknologi Informasi (JNKTI), 2(2), 193-201. 2019

11.Munawir, M., \& Erdiwansyah, E. "Perancangan Portal Informasi Gampong pada Gampong Lambeugak Kecamatan Kuta Cot Glie Aceh Besar”, Jurnal Nasional Komputasi Dan Teknologi Informasi (JNKTI), 1(2), 2018

12.Munawir, M., \& Karmila, K. "Pengembangan Aplikasi Pengusulan pembimbing Tugas Akhir Secara Online Pada Fakultas Teknik Universitas Serambi Mekkah". Jurnal Nasional Komputasi Dan Teknologi Informasi (JNKTI), 1(1), 2018.

13.Utomo, M. R., Witama, M. N., \& Sumarni, R. A. (2020). Perancangan Sistem Informasi Pendaftaran Siswa Baru Berbasis Java Dekstop Pada Madrasah Ibtidaiyah Al-Ihsan”, Jurnal Nasional Komputasi Dan Teknologi Informasi (JNKTI), 2020

14.Amiruddin, A. (2016). Sistem Pendukung Keputusan Pemberian Dana Pengembangan Usaha Agribisnis Pedesaan (Puap) Kepada Gapoktan Menggunakan Metode Simple Additive Weighting (Saw). ILKOM Jurnal Ilmiah, 8(3), 153-159. https://doi.org/10.33096/ilkom.v8i3.82.153-159, 2016

15. Andarinny, A. A., Widodo, C. E., \& Adi, K, "Perancangan Sistem Identifikasi Biometrik Jari Tangan Menggunakan Laplacian Of Gaussian dan Ektraksi Kontur" Youngster Physics Journal, 6(4), 304-314. 2017 